\title{
Effect of Dietary Supplementation of Conventional and Non conventionally Produced Azolla (Azolla pinnata) on Growth Performance of Nellore Lambs
}

\author{
M. Murali Krishna ${ }^{1}$, Ch. Venkata Seshaiah ${ }^{2 *}$, A. Anitha ${ }^{3}$ and D. Srinivas Kumar ${ }^{4}$ \\ ${ }^{1}$ Department of Livestock Production Management, ${ }^{2}$ Department of Animal Nutrition, SVVU, \\ NTR College of Veterinary Science, Gannavaram, Krishna district, Andhra Pradesh, India
}

*Corresponding author

\begin{tabular}{l} 
Ke y w o r d s \\
$\begin{array}{l}\text { Azolla, Dairy farm } \\
\text { liquid waste, } \\
\text { Nellore lambs, } \\
\text { Growth }\end{array}$ \\
\hline Article Info \\
\hline $\begin{array}{l}\text { Accepted: } \\
\text { 15 October } 2020 \\
\text { Available Online: } \\
\text { 10 November } 2020\end{array}$ \\
\hline
\end{tabular}

\section{A B S T R A C T}

A study was carried out to determine the effect of dietary supplementation of azolla grown on dairy farm liquid waste (non conventionally produced) compared to conventionally produced azolla on growth performance of lambs and also to find out its suitability for feeding small ruminants. Eighteen Nellore lambs of about 3-4 months age, having uniform body weights (13-14 kg) were selected and randomly divided into 3 groups of 6 lambs each in a completely randomized design. Control (C) group was fed with conventional diet without azolla, T1 and T2 groups were fed with diets in which $10 \%$ protein in the concentrate feed replaced with azolla produced by conventional and non conventional methods, respectively. The experimental diets were offered to the lambs for a period of 90 days. The average daily gain (g/day) was $73.66 \pm 4.69,72.54 \pm 2.45$ and $73.2 \pm 3.35$, and mean feed conversion ratio (FCR) was 18.83, 19.06 and 18.87 for C, T1, T2 groups, respectively. The cost per kg weight gain for C, T1, T2 groups was Rs 78.47, 73.05 and 69.20 , respectively. The present study revealed that economic growth rates in lambs can be achieved by replacement of conventional protein with azolla. Further azolla obtained from dairy farm liquid waste can safely include in the diets of lambs which is economical compared to conventional azolla.

\section{Introduction}

Azolla is an Aquatic macrophyte floating freely on water and rich in protein, essential amino acids, vitamin A, B12, and b-carotene and minerals like calcium, phosphorus, potassium, iron, copper, manganese, etc (Pillai et al., 2005). Azolla also used for wastewater treatment and is more efficient than terrestrial plants because of their faster growth and larger biomass production, relative higher capability of pollutant uptake and better purification effects due to direct contact with contaminated water (Sood et al., 2012). Azolla can fix atmospheric nitrogen with help of blue green algae, Anabaena azollae, which makes the azolla tend to contain relatively high level of nitrogen and can be a protein source for animal feeding. Several studies have demonstrated earlier that azolla can be used as substrate for feeding sheep, goat, pig, rabbits, and poultry (Pillai $e t$ al., 2002; Satish and Usturge, 2009, Trivedi et al., 2005; Kologi et al., 2009). Since there is a 
paucity of information regarding use of azolla produced from dairy farm liquid waste, the present research was carried to find out its effect on growth and suitability for feeding ruminants.

\section{Materials and Methods}

\section{Animals and experimental design}

Eighteen weaned Nellore lambs of about 3-4 months age were selected from Livestock Farm Complex, NTR College of Veterinary Science, Gannavaram and were randomly divided into three equal groups of six animals each on the basis of body weight in a completely randomized design. The particulars of the experimental lambs and experimental design are presented in the Table 1.

\section{Housing of lambs}

All the experimental lambs were housed in a small animal shed with good ventilation and provision for individual feeding. Fresh, clean drinking water was provided to the animals throughout the day. All the lambs were stallfed throughout the experimental period. Cleanliness and hygiene was maintained in the shed throughout the experimental period.

\section{Azolla production}

For the cultivation of Azolla in the conventional method, 6 cement concrete troughs each having the dimensions $6 \mathrm{ft} \times 2 \mathrm{ft}$ $\times 1 \mathrm{ft}(\mathrm{LXWXD})$ were used. All the troughs were leak proof and having the even bottom. A thin layer of $10 \mathrm{~cm}$ soft soil was spread in the trough such that no large stones or any other contaminants existed. Later, water was filled to a three fourth level in each trough and regular care was taken to maintain the water up to the same level. About $3 \mathrm{~kg}$ of fresh buffalo dung dissolved in 10 liters of water was added into each trough with thorough mixing such that the mixture was spread evenly throughout the area. About $5 \mathrm{~g}$ of super phosphate dissolved in 5 liters of water was added to the soil in a zigzag manner.

Once the preparation was completed, each pit was inoculated with $0.5 \mathrm{~kg}$ of fresh and pure culture of Azolla and water was sprinkled over it. The $\mathrm{pH}$ of the bottom organic matter and the top water were tested regularly. Once in every 15 days, $3 \mathrm{~kg}$ buffalo dung, $5 \mathrm{~g}$ super phosphate and $5 \mathrm{~g}$ of mineral mixture (Ranmix) per tub were added to obtain continuous growth of Azolla and to avoid nutrient deficiency. Azolla was harvested every week from the troughs, washed thoroughly in clean water, weighed and recorded the yield.

The procedure for cultivation of azolla on dairy farm liquid waste (non conventional method) was similar to the conventional method except that the dung was not added. The $\mathrm{P}^{\mathrm{H}}$ of the waster was maintained at 7-8 by addition of small quantity of water depending on the requirement.

\section{Dietary treatments}

The nutrient requirements of the experimental lambs were met from Hybrid Napier green fodder and concentrate mixture as basal diet as per the nutrient requirements (ICAR-2013). Control group was fed with Hybrid Napier green fodder and concentrate feed, T1 was and T2 groups were fed with Hybrid Napier green fodder and concentrate feed in which $10 \%$ of the protein was replaced with Azolla produced from conventional and non conventional methods, respectively. Care was taken that all the experimental rations were isonitrogenous. The composition of the experimental concentrate feed is mentioned in Table 2. 


\section{Results and Discussion}

The mean feed intake $(\mathrm{Kg})$ for $\mathrm{C}, \mathrm{T} 1$ and $\mathrm{T} 2$ groups was $20.81 \pm 1.48,20.74 \pm 1.46$ and $20.73 \pm 1.47$, respectively which was significantly $(\mathrm{P}<0.01)$ higher in $\mathrm{C}$ group compared to azolla supplemented groups, while the difference was not significant among T1 and T2 groups (Table 3). Incorporation of Azolla in the concentrate mixture may be the reason for decreased feed intake in T1 and T2 group lambs. Similar findings of decreased dry matter intake was observed by Ahmed et al., (2016) in sheep and Becerra et al., (1995) in ducks fed with Azolla based diets.

Table.1 Experimental animals and design for growth trial

\begin{tabular}{|l|c|c|c|c|c|c|}
\hline \multirow{5}{*}{} & \multicolumn{2}{|c|}{ C } & \multicolumn{2}{c|}{ T-1 } & \multicolumn{2}{c|}{ T-2 } \\
\hline \multirow{5}{*}{ Tag No } & BW(Kg) & Tag No & BW(Kg) & Tag No & BW(Kg) \\
\cline { 2 - 8 } & 119 & 16.6 & 84 & 16.5 & 136 & 16.4 \\
\cline { 2 - 7 } & 99 & 16.4 & 93 & 16.1 & 85 & 16.0 \\
\cline { 2 - 7 } & 92 & 16.3 & 66 & 15.3 & 128 & 14.3 \\
\cline { 2 - 7 } & E10 & 12 & 94 & 15.1 & R8 & 11.0 \\
\cline { 2 - 7 } & R4 & 10.5 & R9 & 9.6 & R5 & 13.7 \\
\cline { 2 - 7 } & R6 & 9.8 & E12 & 8.6 & E11 & 9.8 \\
\hline Mean & & $\mathbf{1 3 . 6} \pm \mathbf{1 . 3}$ & & $\mathbf{1 3 . 5 3} \pm \mathbf{1 . 4 2}$ & & $\mathbf{1 3 . 5 3 + 1 . 0 8}$ \\
\hline
\end{tabular}

Table.2 Ingredient composition of the experimental concentrate feed

\begin{tabular}{|l|l|c|c|c|}
\hline S.No. & Ingredient & Control & T1 & T2 \\
\hline $\mathbf{1}$ & Maize & 35 & 35 & 35 \\
\hline $\mathbf{2}$ & Dorb & 31 & 31 & 31 \\
\hline $\mathbf{3}$ & Ginguly cake & 11 & 8.0 & 8.0 \\
\hline $\mathbf{4}$ & Soyabean meal & 20 & 17.5 & 17.5 \\
\hline $\mathbf{5}$ & Min mix & 2.0 & 2.0 & 2.0 \\
\hline $\mathbf{6}$ & Salt & 1.0 & 1.0 & 1.0 \\
\hline $\mathbf{7}$ & Azolla & 0 & 9.5 & 9.7 \\
\hline $\mathbf{8}$ & Cost of the ration & 25 & 23 & 23 \\
\hline
\end{tabular}

Table.3 Effect of feeding azolla obtained from conventional and non conventional methods on feed intake in Nellore lambs

\begin{tabular}{|l|l|l|l|}
\hline \multirow{2}{*}{ Fortnight } & \multicolumn{3}{|c|}{ Feed intake (Kg) } \\
\cline { 2 - 4 } & \multicolumn{1}{|c|}{$\mathbf{C}$} & \multicolumn{1}{c|}{ T1 } & \multicolumn{1}{c|}{ T2 } \\
\hline $\mathbf{1}$ & $17.85 \pm 1.26$ & $17.81 \pm 1.25$ & $17.87 \pm 1.27$ \\
\hline $\mathbf{2}$ & $17.92 \pm 1.27$ & $17.86 \pm 1.26$ & $17.94 \pm 1.27$ \\
\hline $\mathbf{3}$ & $17.87 \pm 1.27$ & $17.90 \pm 1.26$ & $17.78 \pm 1.26$ \\
\hline $\mathbf{4}$ & $22.10 \pm 1.57$ & $21.90 \pm 1.54$ & $21.78 \pm 1.54$ \\
\hline $\mathbf{5}$ & $22.30 \pm 1.58$ & $22.23 \pm 1.56$ & $22.21 \pm 1.57$ \\
\hline 6 & $26.85 \pm 1.90$ & $26.74 \pm 1.88$ & $26.82 \pm 1.90$ \\
\hline Overall mean & $\mathbf{2 0 . 8 1}^{\mathbf{a}} \pm 1.48$ & $\mathbf{2 0 . 7 4}^{\mathbf{b}} \pm 1.46$ & $\mathbf{2 0 . 7 3}^{\mathbf{b}} \pm 1.47$ \\
\hline
\end{tabular}

Means with different superscripts row wise differ significantly $(\mathrm{P}<0.01)$ ** 
Table.4 Effect of feeding azolla obtained from conventional and non conventional methods on average daily gain (g/day) in Nellore lambs

\begin{tabular}{|l|c|c|c|}
\hline \multirow{2}{*}{ Fortnight } & \multicolumn{3}{|c|}{ Average daily gain (g/day) } \\
\cline { 2 - 4 } & $\mathbf{C}$ & $\mathbf{T}-\mathbf{1}$ & $\mathbf{T - 2}$ \\
\hline $\mathbf{1}$ & $68.00 \pm 4.33$ & $72.66 \pm 2.45$ & $72.00 \pm 3.29$ \\
\hline $\mathbf{2}$ & $66.66 \pm 4.24$ & $64.00 \pm 2.16$ & $68.00 \pm 3.11$ \\
\hline $\mathbf{3}$ & $59.33 \pm 3.78$ & $67.33 \pm 2.27$ & $62.00 \pm 2.84$ \\
\hline $\mathbf{4}$ & $90.00 \pm 5.73$ & $75.3 \pm 2.54$ & $85.3 \pm 3.90$ \\
\hline $\mathbf{5}$ & $84.00 \pm 5.34$ & $80.60 \pm 2.72$ & $79.3 \pm 3.63$ \\
\hline $\mathbf{6}$ & $74.00 \pm 4.71$ & $75.34 \pm 2.54$ & $72.6 \pm 3.32$ \\
\hline Overall mean & $73.66 \pm 4.69$ & $72.54 \pm 2.45$ & $73.2 \pm 3.35$ \\
\hline
\end{tabular}

Table.5 Effect of feeding azolla obtained from conventional and non conventional methods on cost per kg weight gain in Nellore lambs

\begin{tabular}{|l|c|c|c|}
\hline \multicolumn{1}{|c|}{ Parameter } & \multicolumn{3}{c|}{ Cost of feeding } \\
\cline { 2 - 4 } & C & T-1 & T-2 \\
\hline Mean initial body weight (kg) & $13.6 \pm 1.3$ & $13.53 \pm 1.42$ & $13.53 \pm 1.08$ \\
\hline Mean final body weight (kg) & $20.23 \pm 0.03$ & $20.06 \pm 0.06$ & $20.12 \pm 0.05$ \\
\hline $\begin{array}{l}\text { Mean weight gain (kg) during the } \\
\text { experiment }\end{array}$ & $6.63 \pm 0.06$ & $6.53 \pm 0.04$ & $6.59 \pm 0.05$ \\
\hline Total concentrated feed intake (kg) & 124.86 & 124.44 & 124.38 \\
\hline Feed conversion Ratio & 18.83 & 19.06 & 18.87 \\
\hline $\begin{array}{l}\text { Cost of concentrate feeding per kg } \\
\text { weight gain (Rs) }\end{array}$ & 78.47 & 73.05 & 69.20 \\
\hline
\end{tabular}

The body mean body weights $(\mathrm{kg})$ at the end of the experiment for control, T1 and T2 groups were $20.23 \pm 0.03,20.06 \pm 0.06$ and $20.12 \pm 0.05$, respectively (Table 1). Significant difference in final body weights were not observed among experimental lambs at the end of the experiment. Parallel to the present findings, Ahmed et al., (2016) also reported comparable body weights between control and treatment group of growing sheep at $6 \%$ level replacing linseed cake with Azolla. Even though, the feed intake was less in treatment groups, the comparable body weight gains in T1 and T2 with control group may be due to increased digestibility of azolla based diets. Similar observation of increased digestibility for azolla based diets was reported by Reddy et al., (2009) in goats.
The mean average daily gain (g/day) was73.66 $\pm 4.69,72.54 \pm 2.45$ and $73.2 \pm$ 3.35 for control, $\mathrm{T} 1$ and $\mathrm{T} 2$ groups and the difference was not significant among the groups (Table 4). This was reflected in final body weights among the experimental lambs. Similar non-significant difference between the control and treatment group of growing sheep fed with $6 \%$ level of linseed cake replaced with Azolla reported by Ahmed et al., (2016) is consistence with the present findings. The average daily gain reported in the present study is slightly less compared to the average daily gain in growing sheep reported for control $(83.15 \mathrm{~g})$ and treatment group (82.17 g) by Ahmed et al., (2016). This might be due to variation in breed and environment. 
The mean feed conversion ratio (FCR) for $\mathrm{C}$, $\mathrm{T} 1$ and $\mathrm{T} 2$ group lambs was $18.83,19.06$ and 18.87 , respectively. Much variation was not observed in FCR among the experimental groups. Parallel to the present findings Ahmed et al., (2016) reported similar pattern of FCR in growing sheep fed with azolla based diets. The findings of Saini et al., (2018) in pigs supplemented with 15\% Azolla based diets corroborated with present findings.

The cost per kg weight gain (Rs) for $\mathrm{C}, \mathrm{T} 1$ and T2 was 78.47, 73.05 and 69.20, respectively (Table 5).

Lower cost per $\mathrm{kg}$ weight gain was observed in $\mathrm{T} 2$ group lambs followed by $\mathrm{T} 1$ and was higher in control group. Supplementation of Azolla reduced the requirement of costly protein supplements in the ration and 10\% protein replacement with azolla from conventional and non conventional methods in the concentrate feed saved Rs 5.42 and 9.27, respectively for $\mathrm{kg}$ weight gain in growing lambs. The present findings were consistent with the findings of Ahmed et al., (2016) who reported Rs 2 savings per $\mathrm{kg}$ weight gain in growing sheep fed with Azolla at $6 \%$ level compared to the control. The cost of ration per $\mathrm{kg}$ weight gain was Rs.68.06, 64.42 , and 59.28 in pigs fed with 0,15 , and $20 \%$ levels of azolla meal in the swine rations as a replacement to conventional protein source, respectively (Cherryl et al., 2013) corroborated with present findings. The results reported by Indira et al., (2009) and Kumar et al., (2012) in buffalo calves also consistent with present findings.

Azolla can be cultivated in dairy farm liquid waste which saves water and dung for its production and also helps in recycling of waste water. This study observed that azolla obtained from dairy farm liquid waste is as good as azolla produced from conventional method and can be successfully used as economic protein source in lambs.

\section{Acknowledgements}

The authors are thankful to Sri Venkateswara Veterinary University, Tirupati for providing facilities to carry out the present study.

\section{References}

Ahmed, H. A., Ganai, A. M., Beigh Y.A., Sheikh, G. G. and Reshi, P.A., 2016. Performance of growing sheep on Azolla based diets. Indian J. of Anim. Res. 50 (5): 2016: 721-724.

Becerra, M., Prestone, T. R. and Olge, B., 1995. Effect of replacing whole boiled soya beans with azolla in the diets of growing ducks. Livestock Res, for Rural Deve. 7 (3): Downloaded from http://www.Irrd.org/llrd7/3 /7.htm

Cherryl, D. M., Prasad, R.M.V. and Jayalakshmi, P., 2013. A study on economics of inclusion of Azolla pinnatain swine rations. International $J$. of Agri. Sci. and Vete. Medi. 1(4): 5056.

ICAR, 2013. Nutrient Requirements of Sheep, Goat and Rabbit.

Indria, D., Sarjanrao, K., Suresh, J., Venugopal Naidu, K. and Ravi, A., 2009. Azolla (Azolla pinnata) as a feed supplement in buffalo calves on growth performance. Indian J. of Anim. Nutr. 26:345-348.

Kololgi, S.D., Hosamani, S.V., Malshet Karuna. and Nagaraj, M. S., 2009. Azolla- an organic feed supplement for livestock. National symposium on Organic Livestock Farming-Global issues, trends and challenges, 26-28 th Feb, Kolkata. Pp. 35.

Kumar, D.S., Prasad, R.M.V., Kishore, K.R. and Rao, E.R., 2012. Effect of azolla (Azolla pinnata) based concentrate 
mixture on nutrient utilization in buffalo bulls. Indian J. of Anim. Res. 46:268271.

Pillai, P. K., Premalatha, S. and Rajamony, S., 2005. Azolla: A sustainable feed for livestock. LEISA India, 21(3): 26-27

Reddy, Y.R., Rao, K. S., Sudhakar, K., Gupta, B. R. and Prakash, G. M., 2009. Proceedings of Animal Nutrition Association Conference. Held on 14-17, February, 2009, New Delhi:190

Saini, P. S., Roy, B., Lakhani, G. P., Jain., and A. K., Ghosh, S., 2018. Effect of Azolla (Azolla pinnata) Feeding on Growth Performance and Carcass Traits of Crossbred pigs. International. J. of Current Microbiol. and Appl. Sci. 7(6):3813-3816.

Satish, B. and Usturge, S. M. 2009. Azolla production and Livestock feedingOrganic Farming, National symposium on Organix Livestock Farming- Global issues, trends and challenges, 26-28th Feb, Kolkata. Pp. 21.

Sood, A., Pabbi, S. and Uniyal, P. L, 2011. Effect of paraquat on lipid peroxidation and antioxidant enzymes in aquatic fern Azolla microphylla Kual. Russian J. of Plant Physiol. 58:667-673.

Trivedi, M.M., Parnerkar, S. and Patel, A.M., 2005. Effect of Feeding Nonconventional Creep Mixtures on Growth Performance of Pre-weaned Lambs. International J. of Agri. And Biol. Sci. http://www.ijab.org, 1560-8530//07-2$175-179$

\section{How to cite this article:}

Murali Krishna, M., Ch. Venkata Seshaiah, A. Anitha and Srinivas Kumar, D. 2020. Effect of Dietary Supplementation of Conventional and Non conventionally Produced Azolla (Azolla pinnata) on Growth Performance of Nellore Lambs. Int.J.Curr.Microbiol.App.Sci. 9(11): 20582063. doi: https://doi.org/10.20546/ijcmas.2020.911.245 